\title{
Effect of Pyrophyllite on the Precipitation of Aluminium Sulphate During the Dissolution of Aluminosilicates by Acid Mixtures
}

\author{
Celia Maqueda and José Luis Pérez Rodríguez \\ instituto de Recursos Naturales y Agrobiologia, Apartado 1052, 41080 Seville, Spain \\ and Angel Justo \\ Departamento de Química Inorgánica, Facultad de Farmacia, Apartado 874, Seville, Spain
}

\begin{abstract}
The dissolution of silicate rocks with hydrofluoric - sulphuric - nitric acid mixtures has been studied. When the samples contained pyrophyllite in addition to other silicoaluminate minerals, the pyrophyllite was not attacked and part of the aluminium dissolved and separated from the other minerals and was precipitated as aluminium sulphate with different degrees of hydration.
\end{abstract}

Keywords: Pyrophyllite; silicate dissolution; acid mixtures; aluminium sulphate

A currently accepted method for the analysis of silicates is decomposition by acid mixtures. ${ }^{1-4}$ The dissolution of silicate rocks by digestion with $\mathrm{HF}-\mathrm{HNO}_{3}-\mathrm{HClO}_{4}$ mixtures is a general procedure proposed by Bennett et al..$^{5}$ In a previous paper, Maqueda et al. ${ }^{6}$ have shown that when the sample contains pyrophyllite, dissolution is incomplete.

Bennett and Reed ${ }^{7}$ proposed a method using $\mathrm{HF}-\mathrm{HNO}_{3}$ $\mathrm{H}_{2} \mathrm{SO}_{4}$ for samples containing high proportions of titanium. However, we have found that when the sample contains pyrophylite, its presence produces simultaneous reactions between the dissolved ions and the acid mixture, yielding precipitates of insoluble salts.

In this work the influence of pyrophyllite on the precipitation of insoluble salts during the decomposition of silicate rocks by $\mathrm{H}_{2} \mathrm{SO}_{4}-\mathrm{HNO}_{3}$ has been studied.

\section{Experimental}

\section{Attack Methods}

(a) Nitric - hydrochloric - hydrofluoric acid method

Transfer $0.20 \mathrm{~g}$ of finely ground sample into a PTFE-lined bomb, add $0.25 \mathrm{ml}$ of $\mathrm{HNO}_{3}(65 \%), 0.75 \mathrm{ml}$ of $\mathrm{HCl}(37 \%)$ and $5 \mathrm{ml}$ of $\mathrm{HF}(40 \% \mathrm{~m} / \mathrm{m})$ and heat at $140^{\circ} \mathrm{C}$ for $60 \mathrm{~min}$. Cool to room temperature, add $5 \mathrm{~g}$ of $\mathrm{H}_{3} \mathrm{BO}_{3}$ and heat at $60^{\circ} \mathrm{C}$ in a plastic beaker until the sample has dissolved. Dilute to $250 \mathrm{ml}$ in a plastic flask.

\section{(b) Sample attack method of Bennett et al. 5}

Weigh $0.25 \mathrm{~g}$ of the finely ground sample, add $5 \mathrm{ml}$ of $\mathrm{HNO}_{3}$ $(1+4), 5 \mathrm{ml}$ of $\mathrm{HClO}_{4}(1+4)$ and $10 \mathrm{ml}$ of $\mathrm{HF}(40 \% \mathrm{~m} / \mathrm{m})$ and evaporate to dryness. Cool the residue, add $5 \mathrm{ml}$ of $\mathrm{HClO}_{4}$ $(1+4)$ and evaporate to dryness again. To the cool, dry residue, add $1-2 \mathrm{ml}$ of $\mathrm{HCl}(37 \%)$ and distilled water and warm. Cool, centrifuge, filter and wash several times with distilled water. Determine the different elements in solution by atomic absorption spectrometry.

\section{(c) Sample attack method of Bennett and Reed}

The $\mathrm{H}_{2} \mathrm{SO}_{4}-\mathrm{HNO}_{3}$ acid mixture was prepared by adding 100 $\mathrm{ml}$ of dilute $\mathrm{H}_{2} \mathrm{SO}_{4}(1+1)$ and $250 \mathrm{ml}$ of $\mathrm{HNO}_{3}(65 \% \mathrm{~m} / \mathrm{m}, \mathrm{sp}$. gr. 1.40) to $650 \mathrm{ml}$ of water. Weigh $0.25 \mathrm{~g}$ of finely ground sample. Add $10 \mathrm{ml}$ of the $\mathrm{H}_{2} \mathrm{SO}_{4}-\mathrm{HNO}_{3}$ acid mixture, $10 \mathrm{ml}$ spectrometry.

\section{Diffractometer}

The X-ray diffraction diagrams were obtained in a Siemens Kristalloflex D-500 diffractometer, with Ni-filtered $\mathrm{Cu} \mathrm{K} \alpha$ radiation.

\section{Results and Discussion}

The mineralogical composition of the raw sample used in this work has been deduced by X-ray diffraction. It consists of pyrophyllite (ca. 40\%), mica (ca. 52\%), kaolinite (ca. 5\%) and feldspar $(<5 \%)$. Interstratified mica - smectite and rutile are also present. The sample was treated by the different acid attacks described in the experimental methods and the results are shown in Table 1.

As we have shown in a previous paper ${ }^{6}$ with a sample of similar composition, the attack in the digestion bomb dissolves all the elements completely [Table 1(a)]. After the treatment with the $\mathrm{HF}-\mathrm{HClO}_{4}-\mathrm{HNO}_{3}$ acid mixture, the sample is not completely dissolved [Table $1(b)$ ], a white residue remaining. Iron, calcium, magnesium, sodium and potassium are completely dissolved, whereas aluminium and titanium are not completely dissolved, $6.42 \%$ of aluminium remaining in the residue.

The modes of attack by the $\mathrm{HF}-\mathrm{H}_{2} \mathrm{SO}_{4}-\mathrm{HNO}_{3}$ and $\mathrm{HF}-$ $\mathrm{HNO}_{3}-\mathrm{HClO}_{4}$ acid mixtures are similar, a residue remaining in both instances. Iron, calcium, magnesium, sodium and potassium are dissolved in the same proportions, but aluminium and titanium are not dissolved to the same extent [Table 1(c)].

After dissolution of the sample by the $\mathrm{HF}-\mathrm{H}_{2} \mathrm{SO}_{4}-\mathrm{HNO}_{3}$ acid mixture, more titanium passes into solution, suggesting that this method is better for samples containing titanium, which is not, however, completely dissolved. However, the aluminium concentration is lower with dissolution by this acid attack.

Table 1. Analysis of raw material by ( $a$ ) attack in digestion bomb, $(b)$ attack by $\mathrm{HF}-\mathrm{HNO}_{3}-\mathrm{HClO}_{4}$ and (c) attack by $\mathrm{HF}-\mathrm{H}_{2} \mathrm{SO}_{4}-\mathrm{HNO}_{3}$

of $\mathrm{HF}(40 \% \mathrm{~m} / \mathrm{m})$ and evaporate to dryness. Cool the residue,
add $10 \mathrm{ml}$ of the $\mathrm{H}_{2} \mathrm{SO}_{4}-\mathrm{HNO}_{3}$ acid mixture and evaporate to
dryness again. To the cool, dry residue, add $1-2 \mathrm{ml}$ of $\mathrm{HNO}_{3}$
$(65 \% \mathrm{~m} / \mathrm{m})$ and distilled water and warm. Cool, centrifuge,
filter and wash several times with distilled water. Determine
the different elements in solution by atomic absorption
spectrometry.

of $\mathrm{HF}(40 \% \mathrm{~m} / \mathrm{m})$ and evaporate to dryness. Cool the residue,
add $10 \mathrm{ml}$ of the $\mathrm{H}_{2} \mathrm{SO}_{4}-\mathrm{HNO}_{3}$ acid mixture and evaporate to
dryness again. To the cool, dry residue, add $1-2 \mathrm{ml}$ of $\mathrm{HNO}_{3}$
$(65 \% \mathrm{~m} / \mathrm{m})$ and distilled water and warm. Cool, centrifuge,
filter and wash several times with distilled water. Determine
the different elements in solution by atomic absorption
spect

of $\mathrm{HF}(40 \% \mathrm{~m} / \mathrm{m})$ and evaporate to dryness. Cool the residue,
add $10 \mathrm{ml}$ of the $\mathrm{H}_{2} \mathrm{SO}_{4}-\mathrm{HNO}_{3}$ acid mixture and evaporate to
dryness again. To the cool, dry residue, add $1-2 \mathrm{ml}$ of $\mathrm{HNO}_{3}$
$(65 \% \mathrm{~m} / \mathrm{m})$ and distilled water and warm. Cool, centrifuge,
filter and wash several times with distilled water. Determine
the different elements in solution by atomic absorption
spect

of $\mathrm{HF}(40 \% \mathrm{~m} / \mathrm{m})$ and evaporate to dryness. Cool the residue,
add $10 \mathrm{ml}$ of the $\mathrm{H}_{2} \mathrm{SO}_{4}-\mathrm{HNO}_{3}$ acid mixture and evaporate to
dryness again. To the cool, dry residue, add $1-2 \mathrm{ml}$ of $\mathrm{HNO}_{3}$
$(65 \% \mathrm{~m} / \mathrm{m})$ and distilled water and warm. Cool, centrifuge,
filter and wash several times with distilled water. Determine
the different elements in solution by atomic absorption
spect

of $\mathrm{HF}(40 \% \mathrm{~m} / \mathrm{m})$ and evaporate to dryness. Cool the residue,
add $10 \mathrm{ml}$ of the $\mathrm{H}_{2} \mathrm{SO}_{4}-\mathrm{HNO}_{3}$ acid mixture and evaporate to
dryness again. To the cool, dry residue, add $1-2 \mathrm{ml}$ of $\mathrm{HNO}_{3}$
$(65 \% \mathrm{~m} / \mathrm{m})$ and distilled water and warm. Cool, centrifuge,
filter and wash several times with distilled water. Determine
the different elements in solution by atomic absorption
spect

of $\mathrm{HF}(40 \% \mathrm{~m} / \mathrm{m})$ and evaporate to dryness. Cool the residue,
add $10 \mathrm{ml}$ of the $\mathrm{H}_{2} \mathrm{SO}_{4}-\mathrm{HNO}_{3}$ acid mixture and evaporate to
dryness again. To the cool, dry residue, add $1-2 \mathrm{ml}$ of $\mathrm{HNO}_{3}$
$(65 \% \mathrm{~m} / \mathrm{m})$ and distilled water and warm. Cool, centrifuge,
filter and wash several times with distilled water. Determine
the different elements in solution by atomic absorption
spectrometry.

\section{Component}

(b)

N.d.* 28.34

$\begin{array}{lllllll}\mathrm{K}_{2} \mathrm{O} \quad \ldots & \ldots & . & \ldots & 3.40 & 3.38 & 3.39 \\ \text { Loss on ignition } & \ldots & \ldots & 5.50 & 5.50 & 5.50\end{array}$

* N.d. Not determined. 


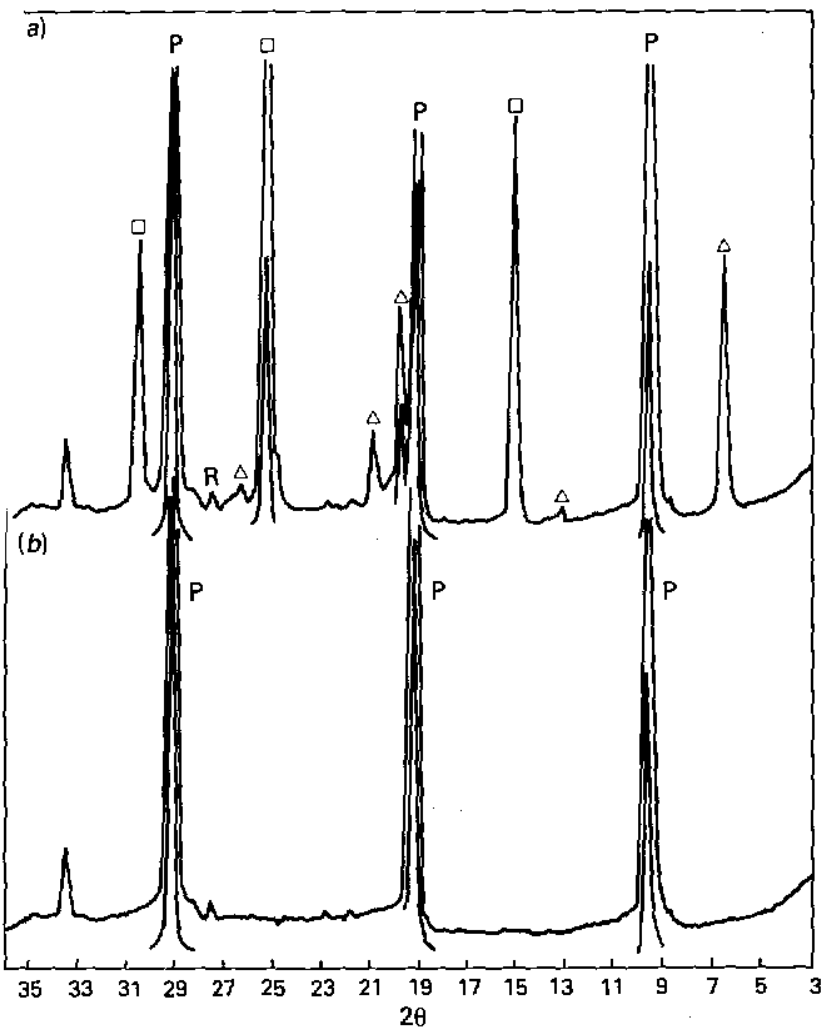

Fig. 1. X-ray powder diffraction patterns of the residues of the attacked sample with $(a) \mathrm{HF}-\mathrm{H}_{2} \mathrm{SO}_{4}-\mathrm{HNO}_{3}$ and $(b) \mathrm{HF}-\mathrm{HNO}_{3}$ $\mathrm{HClO}_{4} . \triangle, \mathrm{Al}_{2}\left(\mathrm{SO}_{4}\right)_{3} .17 \mathrm{H}_{2} \mathrm{O} ; \square, \mathrm{Al}_{2}\left(\mathrm{SO}_{4}\right)_{3} ; \mathrm{P}$, pyrophyllite; and $\mathrm{R}$, rutile

In order to establish the effects of both acid attacks on the sample, the residues were studied by $\mathrm{X}$-ray diffraction (Fig. 1). The residue from the $\mathrm{HF}-\mathrm{HNO}_{3}-\mathrm{HClO}_{4}$ acid mixture consists of pyrophyllite and rutile (Fig. 1(b)], as indicated in a previous paper. 6

The $\mathrm{X}$-ray diffraction diagram of the residue from the $\mathrm{HF}$ $\mathrm{H}_{2} \mathrm{SO}_{4}-\mathrm{HNO}_{3}$ acid mixture is shown in Fig. $1(a)$. In addition to pyrophyllite (reflections at $9.20,4.60$ and $3.06 \AA$ ) and rutile (reflections at 3.24 and $2.48 \AA$ ), the pattern shows that the residue contains other crystalline compounds. The diffraction peaks at $13.39,6.72$ and $4.48 \AA$ correspond to $\mathrm{Al}_{2}\left(\mathrm{SO}_{4}\right)_{3} .17 \mathrm{H}_{2} \mathrm{O}$ and those at 5.78, 4.27, 3.50 and $2.92 \AA$ correspond to $\mathrm{Al}_{2}\left(\mathrm{SO}_{4}\right)_{3}$.
In order to determine the influence of the pyrophyllite on the precipitation of insoluble salts during the acid attack, artificial mixtures of several minerals with and without pyrophyllite were treated with the $\mathrm{HF}-\mathrm{H}_{2} \mathrm{SO}_{4}-\mathrm{HNO}_{3}$ mixture. The following mineral mixtures were used:

(1) $0.2 \mathrm{~g}$ of pyrophyllite, $0.1 \mathrm{~g}$ of illite, $0.1 \mathrm{~g}$ of kaolinite and $0.1 \mathrm{~g}$ of quartz.

(1a) $0.2 \mathrm{~g}$ of illite, $0.2 \mathrm{~g}$ of kaolinite and $0.1 \mathrm{~g}$ of quartz.

(2) $0.3 \mathrm{~g}$ of pyrophyllite and $0.2 \mathrm{~g}$ of kaolinite.

(2a) $0.25 \mathrm{~g}$ of kaolinite.

(3) $0.3 \mathrm{~g}$ of muscovite and $0.2 \mathrm{~g}$ of pyrophyllite.

(3a) $0.25 \mathrm{~g}$ of muscovite.

In the experiments in which pyrophyllite is not present $(1 a$, $2 a$ and $3 a$ ), complete dissolution is achieved. However, when pyrophyllite is present in the synthetic mixtures (1,2 and 3 ), their behaviour is similar to the raw material described previously, aluminium sulphate always being present in different degrees of hydration in the residues.

\section{Conclusion}

The acid attack of mineral samples containing pyrophyllite by mixtures of $\mathrm{HF}-\mathrm{HNO}_{3}-\mathrm{HClO}_{4}$ or $\mathrm{HF}-\mathrm{H}_{2} \mathrm{SO}_{4}-\mathrm{HNO}_{3}$ is not useful. With the first mixture, a residue of pyrophyllite and rutile was found. When acid attack was carried out with the second mixture, the presence of pyrophyllite induced precipitation of part of the dissolved aluminium as aluminium sulphate.

\section{References}

1. Abbey, S., Geol. Surv. Can. Pap., 1967, No. 67-37.

2. Belt, C. B., Anal. Chem., 1967, 39, 676 .

3. Bemas, B., Anal. Chem., 1968, 40, 1682.

4. Neuerberg, G. J., J. Res. U.S. Geol. Surv., 1975, 3, 377.

5. Bennett, H., Early, R. P., Hawley, W. G., and Thwaites, I., Trans. Br. Ceram. Soc., 1962, 61, 636.

6. Maqueda, C., Pérez Rodríguez, J. L., and Justo, A., Analyst, 1986, 111, 1107.

7. Bennett, H., and Reed, R. A., "Chemical Methods of Silicate Analysis," Academic Press, London and New York, for British Ceramic Research Association, 1971.

Paper A61433

Received November 17th, 1986 Accepted January 27th, 1987 